REPORTS OF MORPHOLOGY
$\begin{gathered}\text { Official Journal of the Scientific Society of Anatomists, } \\ \text { Histologists, Embryologists and Topographic Anatomists } \\ \text { of Ukraine } \\ \text { journal homepage: https://morphology-journal.com }\end{gathered}$

\title{
Regression models of individual cephalometric indicators used in the method of E.P. Harvold
}

\author{
Chernysh A.V. ${ }^{1}$, Hasiuk P.A. ${ }^{2}$, Yasko V.V. ${ }^{1}$, Smolko D.G. ${ }^{1}$
}

${ }^{1}$ National Pirogov Memorial Medical University, Vinnytsya, Ukraine

${ }^{2}$ Ivan Horbachevsky Ternopil State Medical University, Ternopil, Ukraine

\section{ARTICLE INFO}

Received: 5 October, 2018

Accepted: 5 November, 2018

UDC: $616-073.75: 616.314 .26-053.81$

\section{CORRESPONDING AUTHOR}

e-mail: andre.chernysh@gmail.com Chernysh A.V.

\begin{abstract}
Many scientific studies have shown the superiority of the Harvold method when performing linear measurements for both the upper and lower jaw. The purpose of the work is to construct and analyze the regression models of teleroentgenographic indices used in the method of E.P. Harvold young men and women with normal occlusion close to orthognathic bite and harmonic face. The analysis of lateral teleroentgenograms of 38 young men (aged from 17 to 21) and 55 young women (aged from 16 to 20 years) with normal occlusion close to orthognathic bite and harmonic face, obtained using the Veraviewepocs 3D device, Morita (Japan), was performed according to the techniques of R.M. Ricketts, C.J. Burstone, E.P. Harvold. In the course of the study, all the indicators of the above methods, were divided into three groups: 1 - metric characteristics of the skull, which usually do not change during surgical and orthodontic treatment; 2 - indicators of the tooth-jaw system that allow people with already formed bone skeleton to change the width, length, angles and position of the bones of the upper and lower jaws; 3 - indicators that characterize the position of each individual tooth relative to each other, to the bony cranial structures and face profile. In the licensed package "Statistica 6.0", regression models were constructed for the following parameters included in the second group, depending on the parameters of the first group: ANS-Cond (maxillary length in the Harvold method described as TM-ANS), Pog-Cond (mandibular length in the E.P. Harvold method is indicated as TM-PGN), Max-Mand - (difference in jaw lengths); as well as the index included in the third group, depending on the indicators of the first and second groups Ap1uAp1I-DOP (angle Ap1uAp1l-DOP). In the young men, all three possible reliable models of teleroentgenographic parameters were constructed using the E.P. Harvold method, which were included in the second group, depending on the indicators of the first group $\left(R^{2}=\right.$ from 0.616 to 0.940$)$, and in young women only the length of the upper and lower jaws ( $R^{2}=0.857$ and 0.792$)$. In both young men and women, all models of the second group of models built according to the indicators of the first group included the distance P-PTV. Up to two models for young men and one model for young women included the distance Pt-N. Also, one model for young men and women included the angle of the cranial tilt (POr-NBa). Only young women have models for the front length of the skull base ( $N-C C)$. As for young men and women, we also built a reliable model of the third group indicator, depending on the indicators of the first and second groups (the angle Ap1uAp1l-DOP) (respectively, $R^{2}=0.626$ and $R^{2}=0.584$ ). And in young men and women, the size of the distance $A-B$ is included to the constructed regression equations. In addition, in young men, the regression equation includes the value of the distance P-PTV; while in young women - the angles of the ANS-Xi-PM, MeGo-NPog and N-CF-A, as well as the difference in jaw lengths Max-Mand.
\end{abstract}

Keywords: regression analysis, cephalometry, Harvold analysis, young men and women, orthognathic bite.

\section{Introduction}

One way of forming a correct and beautiful smile is to use a cephalometric analysis, which is the clinical point of applying cephalometry. The basis of this analysis is the determination of the relationship between the dental and 
skeletal facial structures, which is possible when performing the X-ray method of investigation, in the majority of cases lateral teleroentgenograms $[4,17]$.

During the 19th century, orthodontists offered many techniques, each of which has its own specifics, advantages and disadvantages and, depending on this, has been recognized or practically not used in practice. It should be noted that a significant widely used have cephalometric analysis by McNamara [1, 16], Legan-Burstone [2, 7, 20, 22], Steiner [12], Tweed [5, 18], Ricketts [6], Schwartz [13], Jarabak Bjork [19] and Harvold [15].

In our opinion, the last author and his technique deserves special attention. Thus, Egil Peter Harvold, before becoming a well-known American scientist, worked as an orthodontist in Norway, and defended his doctorate dissertation on anatomy in Oslo in 1954. It was during this period that he began to be interested in the topic of congenital defects of the face (cheiloschisis, etc.), which became the basis of the research topic for the next decades, and already in 1963 he became director of the Center of Cranio-Facial anomalies in San- Francisco In 1974, he first published work, the basis of his own method of cephalometric analysis [15].

The main feature of the Harvold technique was the creation of standards for the length of the upper and lower jaws. Particular attention is drawn to the ratio of the size of the upper and lower jaw. At the same time - the location of teeth for this technique is not important [14].

The method of analysis has not lost its relevance yet and is the subject of many foreign authors' work. Thus, Singh A.K. with co-authors [21] compared the effectiveness of using different methods of cephalometric analysis in order to fix the maxillary-mandibular ratio. The study was attended by 50 people ( 25 girls and 25 boys) aged 18 to 26 years old, without orthodontic or dental treatment in history with orthognathic facial features. After statistical data processing, it was discovered that the Harvold method is a method of choice if it is impossible to conduct a teleroentgenographic study in the natural state of the head.

Wu B.W., Kaban L.B., and Peacock Z.S. [23] compared the effectiveness of Harvold and Steiner's methods for orthogonathic surgery. A retrospective study was conducted at Massachusetts Hospital between 2012 and 2016 and covered 388 patients, of which 289 were included in the study. The study showed the superiority of the E.P. Harvold method when performing linear measurements for both the upper and lower jaw - they were more likely with clinical assessments.

The purpose of the work is to construct and analyze the regression models of teleroentgenographic indices used in the method of E.P. Harvold in young men and women with normal occlusion close to orthognathic bite and harmonic face.

\section{Materials and methods}

Primary lateral teleroentgenograms of 38 young men (aged 17-21 years) and 55 young women (aged 16-20 years) with normal occlusion close to orthognathic bite and harmonic face, obtained from the Veraviewepocs 3D device, Morita (Japan), taken from the bank data of research center of National Pirogov Memorial Medical University, Vinnytsya.

The analysis of lateral teleroentgenograms was carried out according to the methods of R.M. Ricketts, C.J. Burstone, E.P. Harvold, described in detail in previous studies [8, 9, $11]$.

In the course of the study, all the indicators of the above methods, we were divided into three groups. The first group included metric characteristics of the skull, which usually do not change during surgical and orthodontic treatment. Most of these indicators are basic in modern cephalometric analyzes. In relation to them, lateral teleroentgenograms determine the inclination, anterior-posterior or vertical position of the bone structures (upper and lower jaw, occlusal plane, individual teeth). The second group includes indicators of the tooth-jaw system, the definitions of which most often need to be guided by the orthodontic treatment of growing patients and orthodontic surgery, which allows people with already formed bone skeleton to change the width, length, angles and position of the bones of the upper and lower jaws. The third group includes indicators that actually characterize the position of each individual tooth relative to each other, to the bony cranial structures and face profile.

According to the cephalometric method of E.P. Harvold [15], we carried out the simulation of the following indicators included in the second group, depending on the indicators of the first group (Fig. 1):

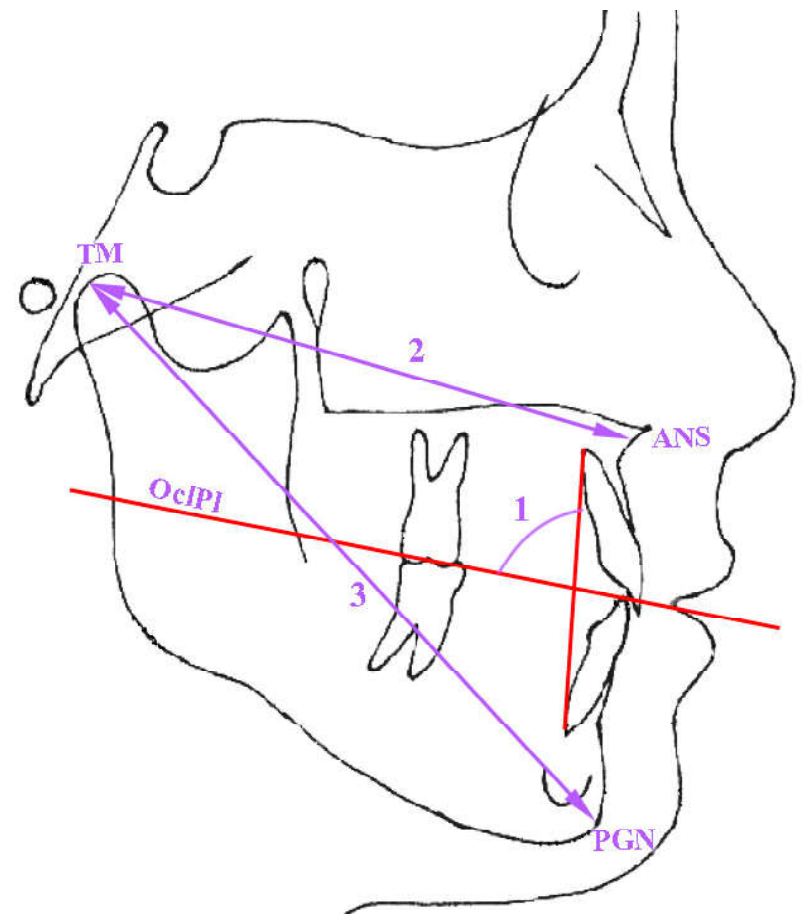

Fig. 1. Teleroentgenographic indicators used in the method of E.P. Harvold. 1 - angle Ap1uAp1I-DOP; 2 - distance ANS-Cond (TMANS); 3 - distance Pog-Cond (TM-PGN). 
ANS-Cond (maxillary length, in the method E.P. Harvold is marked as TM-ANS) - distance from point TM to point $\underline{\text { ANS }}$ (anterior nasal spine), determining the maxillary length $(\mathrm{mm})$;

Pog-Cond (mandibular length, in the method E.P. Harvold is marked as TM-PGN) - distance from point TM to point PGN, determining the mandibular length $(\mathrm{mm})$;

Max-Mand - (Difference in Jaw Lengths) - difference of the lengths of the lines TM-ANS and TM- PGN $(\mathrm{mm})$.

The modeling of E.P. Harvold, which was included in the third group, depending on the indicators of the first and second groups (see Fig. 1), was also conducted:

Ap1uAp1I-DOP - (angle Ap1uAp1I-DOP) - angle between Occlusal Plane and the connecting line between the root tips of the central upper and lower incisor $\left({ }^{\circ}\right)$.

The construction of regression models of individual teleroentgenographic indicators used in the method of E.P. Harvold was carried out in the licensed package "Statistica 6.0". In the direct stepwise regression analysis, we determined the following conditions: 1 - the final version of the regression equation should have a determination coefficient of not less than $0.50 ; 2$ - the value of the F-criterion is not less than 3.0; 3 - the number of free members included in the regression equation should be as low as possible.

\section{Results}

The results of modeling of teleroentgenographic indices by the method of E.P. Harvold, which belonged to the second group, depending on the indicators of the first group, have the form of the following linear equations.

For young men:

ANS-Cond $=7.934+0.988 \times$ Pt-N $-0.716 \times$ P-PTV $\left(R^{2}=0.931 ; F_{(2.35)}=236.0 ; p<0.001 ;\right.$ Error of estimate=3.515),

Pog-Cond $=-1.318+1.088 \times$ Pt-N $-1.450 \times$ P-PTV $\left(R^{2}=0.940 ; F_{(2.35)}=272.1 ; p<0.001 ;\right.$ Error of estimate=4.617),

Max-Mand $=-19.55-0.869 \times$ P-PTV $+0.396 \times$ POR-NBA $\left(R^{2}=0.616 ; F_{(2.35)}=28.12 ; p<0.001\right.$; Error of estimate=4.354),

where here and in the future, $R^{2}$ - coefficient of

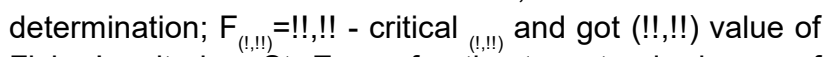
Fisher's criterion; St. Error of estimate - standard error of the standardized regression coefficient; POr-NBa - the angle of the cranial tilt (deflection), the angle formed by the lines $\mathrm{Po}-\mathrm{Or}$ and $\mathrm{Ba}-\mathrm{N}\left({ }^{\circ}\right)$; P-PTV - distance from the point $\underline{P o}$ to the point $\underline{\mathrm{Pt}}$, parallel to the Frankfurt plane $(\mathrm{mm}) ; \mathrm{Pt}-\mathrm{N}$ - the front part of the base of the skull, the distance from the point $\underline{P t}$ to the point $\underline{\mathrm{N}}$, determines the length of the front of the skull base $(\mathrm{mm})$.

For young women:

ANS-Cond $=-5.672-1.060 \times$ P-PTV $+0.812 \times \mathrm{Pt}-\mathrm{N}+$ $0.290 \times$ POr-NBa $\left(R^{2}=0.857 ; F_{(3.51)}=102.2 ; p<0.001\right.$; Error of estimate $=2.801$ ),
Pog-Cond $=-0.847+1.209 \times \mathrm{N}-\mathrm{CC}-1.095 \times \mathrm{P}-\mathrm{PTV}$ $\left(R^{2}=0.792 ; F_{(2.52)}=98.73 ; p<0.001\right.$; Error of estimate=4.656),

where here and in the future, N-CC - front length of the skull base, distance from the point $\underline{N}$ to the point $\underline{\mathrm{C}}(\mathrm{mm})$.

The determination coefficient of the regression equation of the difference in jaw lengths (Max-Mand) in young women with orthognathic bite is 0.328 and therefore has no practical significance for orthodontists.

The results of simulation of teleroentgenographic indices by the method of E.P. Harvold included in the third group, depending on the indicators of the first and second groups, have the form of the following linear equations.

For young men:

AP1UAP1L $=96.28-1.131 \times$ A-B $+0.140 \times$ P-PTV $\left(R^{2}=0.626 ; F_{(2.35)}=29.24 ; p<0.001\right.$; Error of estimate=2.550),

where here and in the future, A-B - distance from the point $\underline{A}$ to the point $\underline{B}$ on the occlusal plane (apOcP-ppOcP) $(\mathrm{mm})$.

$$
\text { For young women: }
$$

AP1UAP1L $=110.0-1.062 \times A-B-0.297 \times$ MeGo-NPog $0.320 \times$ ANS-Xi-PM $+0.180 \times$ Max-Mand $+0.193 \times$ N-CF-A $\left(R^{2}=0.584 ; F_{(5.49)}=13.74 ; p<0.001\right.$; Error of estimate=2.849),

where, ANS-Xi-PM - angle of the lower height of the face, the angle is formed by lines ANS-Xi and $\underline{\mathrm{Xi}-\mathrm{Pm}}\left({ }^{\circ}\right)$; Max-Mand - difference in jaw lengths, difference between length TM-ANS and TM-PGN (mm); MeGo-NPog - facial cone, angle formed by lines Me-Go and N-Pog $\left({ }^{\circ}\right)$; N-CF-A - angle of the upper jaw, angle formed by lines $\underline{\mathrm{N}-\mathrm{CF}}$ and CF-A $\left({ }^{\circ}\right)$.

\section{Discussion}

In a number of studies, the study of ethnic, regional, age and sexual characteristics of the Harvold method has been studied. Alam M. K. and co-authors [3] identified features of cephalometric indices for Bangladesh. In the analysis of 100 lateral teleroentgenograms from ethnic Bangladesh, 50 men and women aged 18-24 years old, it has been found that practically all indicators, except position of the incisors, are in accordance with the Harvold methodology. Also, signs of sexual dimorphism were revealed.

Daer A.A. and Abuaffan A.H. [10] in 2016 set normative indicators for the population of Yemen. For this purpose, a group of volunteers from 105 women and 89 men aged 18-25 who had a symmetrical face and no dental or orthodontic interventions in history were formed. After statistical analysis, there were significant differences for such skeletal indices as SNB, ANB, SNPg and SNBa angles, and distances ML-NL, NL-NSL, ML-NSL and Gntgo-Ar.

However, the work of domestic scientists in the study of 
the method of E.P. Harvold remains small [8], which has negative consequences for the full use of this technique in order to provide orthodontic care to the Ukrainian people.

In young men with orthognathic bite and harmonious face we have constructed all three possible reliable models (length of the upper and lower jaw and difference in jaw lengths) of teleroentgenographic indices using the E.P. Harvold method with a determination coefficient of greater than 0.5 which are included in the second group depending on the indicators of the first group, and in young women only the length of the upper and lower jaws. It is established that in similar models in young men, the determination coefficient in models is higher than in young women (in young men $\mathrm{R}^{2}=0.931$ and 0.940 , and in young women 0.857 and 0.792 ). In both young men and women, all models of the second group of models built according to the indicators of the first group included the distance $\mathrm{P}$ PTV. Two models for young men and one model for young women included the distance $\mathrm{Pt}-\mathrm{N}$, which defines the length of the anterior part of the base of the skull. Also, entered one model for young men and women - angle of the cranial tilt (POr-NBa). Only in young women the models of teleroentgenographic indices by the method of E.P. Harvold which entered the second group, depending on the indicators of the first group includes the front length of the base of the skull (N-CC).

In both young men and women also constructed a reliable model of the angle Ap1uAp1I-DOP (the third group indicator, depending on the indicators of the first and second groups) (respectively, $\mathrm{R}^{2}=0.626$ and $\mathrm{R}^{2}=0.584$ ). And in young men and women, the size of the distance A-B included in the constructed regression equations. In addition, in young

\section{References}

[1]Al Sabbagh, R. (2014). Syrian norms of McNamara cephalometric analysis. International Arab Journal of Dentistry, 3(5), 95101.

[2] Al Taki, A., Yaqoub, S., \& Hassan, M. (2018). Legan-Burstone soft tissue profile values in a Circassian adult sample. Journal of orthodontic science, 7,18 .

[3] Alam, M. K., Basri, R., Purmal, K., Sikder, M. A., Saifuddin, M., \& lida, J. (2013). Cephalometric norms in Bangladeshi adults using Harvold's analysis. International Medical Journal, 20(1), 92-94.

[4] Argancev, A. P., \& Ahmedova, Z. R. (2014). Features of X-ray examination with endodontic treatment. Endodontics today, 3 , 13-19.

[5] Atit, M. B., Deshmukh, S. V., Rahalkar, J., Subramanian, V., Naik, C., \& Darda, M. (2013). Mean values of Steiner, Tweed, Ricketts and McNamara analysis in Maratha ethnic population: A cephalometric study. APOS Trends in Orthodontics, 3(5), 137151.

[6] Bae, E. J., Kwon, H. J., \& Kwon, O. W. (2014). Changes in longitudinal craniofacial growth in subjects with normal occlusions using the Ricketts analysis. The Korean Journal of Orthodontics, 44(2), 77-87.

[7] Bagwan, A. A., AL-Shennawy, M. I., \& Alskhawy, M. M. (2015). Evaluation of soft tissue parameters for adults with accepted occlusion using Legan and Burstone analysis. Tanta Dental men, the regression equation includes the value of the distance P-PTV; while in young women - angles of the ANSXi-PM, MeGo-NPog and N-CF-A, as well as the difference in jaw lengths Max-Mand.

The above-mentioned perspectives on the possibilities of full (taking into account age, gender, ethnicity, etc.) use of the method of E.P. Harvold encourages further study of this topic and the development of regression models of individual teleroentgenographic indicators used in this method in other regions of Ukraine.

\section{Conclusions}

1. In the young men, with normal occlusion close to the orthognathic bite, all three reliable valid models of teleroentgenographic indices according to E.P. Harvold method, included the second group depending on the indicators of the first group $\left(R^{2}=\right.$ from 0.616 to 0.940$)$, and in young women only 2 models $\left(R^{2}=0.857\right.$ and 0.792$)$; both in young men and women, a reliable model of the angle Ap1uAp1I-DOP (the third group indicator, depending on the indicators of the first and second groups) was constructed (respectively, $\mathrm{R}^{2}=0.626$ and $\mathrm{R}^{2}=0.584$ ).

2 . In both young men and women, for all models of second-group teleroentgenographic models constructed by E.P. Harvold method, depending on the indicators of the first group, the distance P-PTV was entered. In addition, up to two models in young men and one model in young women entered the distance Pt-N.

3 . In both young men and women, among the teleroentgenographic indices of the first and second groups that are included in the models of the third group by the method of E.P. Harvold, the distance A-B entered.

Journal, 12(1), 1-6.

[8] Chernysh, A. V. (2018). Cephalometric studies of Ukrainian young men and women with orthognathic bite by the method of E.P. Harvold. Reports of Morphology, 23(2), 38-43. https:// doi.org/10.31393/morphology-jornal-2018-24(2)-06

[9] Chernysh, A. V., Gunas, I. V., Gavryluk, A. O., Dmytrenko, S. V., Serebrennikova, O. A., Kyrychenko, Y. V., \& Balynska, M. V. (2018). Cephalometric studies of ukrainian boys and girls with orthognathic bite by the method of R. M. Ricketts. World of Medicine and Biology, 14(64), 88-93. doi: https://doi.org/ 10.26724/2079-8334-2018-2-64-88-93

[10] Daer, A. A., \& Abuaffan, A. H. (2016). Cephalometric norms among a sample of Yamani adults. Orthodontic Waves, 75(2), 35-40. https://doi.org/10.1016/j.odw.2016.03.001

[11] Dmitriev, M., Chernysh, A., \& Chugu, T. (2018). Cephalometric studies of Ukrainian boys and girls with physiological bite by the method of Charles J. Burstone. Biomedical and Biosocial Anthropology, 30, 62-67. doi: https://doi.org/10.31393/bba302018-09

[12] Dmitriev, M. O. (2016). Determination of normative cephalometric parameters by the method of Stainer for Ukrainian boys and girls. World of Medicine and Biology, 3, 28-32.

[13] Dmitriev, M. O., Chugu, T. V., Gerasimchuk, V. V., \& Cherkasova, O. V. (2017). Determination of craniometric and gnatometric indices by A. M. Schwartz's method for Ukrainian boys and 
girls. Biomedical and biosocial anthropology, 29, 53-58.

[14] Fadeev, R. A., \& Yakovishina, Ye. A. (2013). Studying the diagnostic value of the Harvold EP lateral teleroentgenograms analysis method for determining the age parameters of the upper and lower jaws in growing patients. Institute of Dentistry, 4, 40-41.

[15] Harvold, E. P. (1974). The activator in orthodontics. St. Louis, Mo., Mosby.

[16] Khan, S. A., Mohammad, P. A., Tariq, J., Khursheed, T., Jehan, S., Alam, M. K., \& Qamruddin, I. (2017). Cephalometric Study of Pakistani Population Using McNamaraAnalysis. International Medical Journal, 24(1), 144-146.

[17] Korobeinikova, Yu. L. (2013). Comparative characteristic of modern X-ray methods of diagnostics in dentistry. Actual problems of modern medicine: Bulletin of the Ukrainian Medical Stomatological Academy, 13(3), 44-46.

[18] Kuramae, M., de Araujo Magnani, M. B. B., Nouer, D. F., Ambrosano, G. M. B., \& Inoue, R. C. (2016). Analysis of Tweed's Facial Triangle in Black Brazilian youngsters with normal occlusion. Brazilian Journal of Oral Sciences, 3(8), 401-403.

[19] Mahroof, V. (2017). A Cephalometric Analysis for Pakistani
Adults Using Jarabak Bjork's Analysis. International medical journal, 24(1), 128-131.

[20] Sahoo, N., Mohanty, R., Mohanty, P., Nayak, T., Nanda, S. B., \& Garabadu, A. (2016). Cephalometric Norms for East Indian Population using Burstone Legan Analysis. Journal of International Oral Health, 8(12), 1076-1081.

[21] Singh, A. K., Ganeshkar, S. V., Mehrotra, P., \& Bhagchandani, J. (2013). Comparison of different parameters for recording sagittal maxillo mandibular relation using natural head posture: A cephalometric study. Journal of orthodontic science, 2(1), 16-22. doi: 10.4103/2278-0203.110328

[22] Soni, A., Alladwar, N., Goel, S., Chopra, R., \& Sharma, S. (2015). Evaluation of lateral Cephalometric Norms for Burstone's Analysis in Chhattisgarh by using Nemoceph Software with Lateral Cephalograms Taken in Natural Head Position'. International Journal of Oral Health Dentistry, 1(3), 114-119.

[23] Wu, B. W., Kaban, L. B., \& Peacock, Z. S. (2018). Do Steiner or Harvold Cephalometric Analyses Better Correlate with Clinical Impression in Orthognathic Surgery Patients? Journal of Oral and Maxillofacial Surgery, 76(10), 15-16. DOI: https://doi.org/ 10.1016/j.joms.2018.06.055

\section{РЕГРЕСІЙНІ МОДЕЛІ ІНДИВІДУАЛЬНИХ ЦЕФАЛОМЕТРИЧНИХ ПОКАЗНИКІВ, ЩО ВИКОРИСТОВУЮТЬСЯ В МЕТОДИЦІ E.P. HARVOLD \\ Черниш А.В., Гасюк П.А., Ясько В.В., Смолко Д.Г.}

У багатьох наукових дослідженнях при проведенні лінійних вимірювань як для верхньої, так і для нижньої щелеп, доведено перевагу методики Harvold. Мета роботи - побудувати та провести аналіз регресійних моделей телерентгенографрічних показників, що використовуються у методиці E.P. Harvold, в юнаків і дівчат з нормальною оклюзією, наближеною до ортогнатичного прикусу, та гармонійним обличчям. Аналіз бокових телерентгенограм 38 юнаків (віком від 17 до 21 року) та 55 дівчат (віком від 16 до 20 років) з нормальною оклюзією, наближеною до ортогнатичного прикусу та гармонійним обличчям, отримані за допомогою пристрою Veraviewepocs 3D, Моріта (Япония), проводили за методиками R.M. Ricketts, C.J. Burstone, E.P. Harvold. При проведенні дослідження усі показники вищевказаних методик були розділені на три групи: 1 - метричні характеристики черепа, які, зазвичай, не змінюються під час хірургічного та ортодонтичного лікування; 2 - показники зубощелепної системи, котрі дозволяють в осіб зі вже сформованим кістковим скелетом змінювати ширину, довжину, кути та положення кісток верхньої та нижньої щелеп; 3 - показники, котрі власне характеризують положення кожного окремого зуба по відношенню один до одного, до кісткових черепних структур та профрілю обличчя. В ліцензійному пакеті "Statistica 6.0" будували регресійні моделі наступних показників, що увійшли до другої групи в залежності від показників першої групи: ANS-Cond (довжина верхньої щелепи, у методиці E.P. Harvold зазначається як TM-ANS), Pog-Сond (довжина нижньої щелепи, в методиці E.P. Harvold зазначається як TM-PGN), Max-Mand - (міжщелепна різниця); а також показника, що увійшов до третьої групи в залежності від показників першої та другої груп - Ap1uAp1I-DOP (кут Ap1uAp1I-DOP). В юнаків побудовані усі 3 можливі достовірні моделі телерентгенографрічних показників за методикою E.P. Harvold, які увійшли до другої групи в залежності від показників першої групи $\left(R^{2}=\right.$ від 0,616 до 0,940), а у дівчат - лише довжина верхньої та нижньої щелеп $\left(R^{2}=\right.$ 0,857 і 0,792). Як в юнаків, так і у дівчат до усіх побудованих моделей показників другої групи в залежності від показників першої групи увійшла відстань P-PTV. До двох моделей в юнаків і до одної моделі у дівчат увійшла відстань Pt-N. Tакож до однієї моделі в юнаків і дівчат увійшов кут краніального нахилу (POr-NBa). Лише у дівчат до моделей входить передня довжина основи черепа (N-CC). Як в юнаків, так і у дівчат нами також побудована можлива достовірна модель показника третьої групи в залежності від показників першої та другої груп (кута Ap1uAp1I-DOP) (відповідно $R^{2}=0,626$ ma $\left.R^{2}=0,584\right)$. I в юнаків, і у дівчат до побудованих регресійних рівнянь входить величина відстані А-В. Крім того, в юнаків до регресійного рівняння входить величина відстані P-PTV; а у дівчат - величина кутів ANS-Xi-PM, MeGo-NPog i N-CF-A, а також міжщелепна різниця Max-Mand.

Ключові слова: регресійний аналіз, цефалометрія, аналіз Наrvold, юнакі та дівчата, ортогнатичний прикус.

\section{РЕГРЕССИОННЫЕ МОДЕЛИ ИНДИВИДУАЛЬНЫХ ЦЕФАЛОМЕТРИЧЕСКИХ ПОКАЗАТЕЛЕЙ, ИСПОЛЬЗУЕМЫХ В МЕТОДИКЕ E.P. HARVOLD}

Черниш А.В., Гасюк П.А., Ясько В.В., Смолко Д.Г.

Во многих научных исследованиях доказано преимущество методики Harvold при проведении линейных измерений, как для верхней, так и для нижней челюстей. Цель работы - построить и провести анализ регрессионных моделей телерентгенографрических показателей, используемых в методике E.P. Harvold, у юношей и девушек с нормальной окклюзией, приближенной к ортогнатическому прикусу, и гармоничным лицом. Анализ боковых телерентгенограмм 38 юношей (в возрасте от 17 до 21 года) и 55 девочек (в возрасте от 16 до 20 лет) с нормальной окклюзией, приближенной к ортогнатическому прикусу и гармоничным лицом, полученные с помощью устройства Veraviewepocs 3D, Морита (Япония), проводили по методикам R.M. Ricketts, C.J. Burstone, E.P. Harvold. При проведении исследования все показатели вышеуказанных 
методик, были разделены на три группы: 1 - метрические характеристики черепа, которые обычно не меняются в ходе хирургического и ортодонтического лечения; 2 - показатели зубочелюстной системы, позволяющие у лиц с уже сформированным костным скелетом изменять ширину, длину, углы и положения костей верхней и нижней челюстей 3 показатели, которые собственно характеризируют положение каждого отдельного зуба по отношению друг к другу, к костным черепным структурам и профилю лица. В лицензионном пакете "Statistica 6.0" построены регрессионные модели следующих показателей, вошедшuх во вторую группу в зависимости от показателей первой группы: ANS-Сопd (длина верхней челюсти, в методике E.P. Harvold отмечается как TM-ANS), Pog-Cond (длина нижней челюсти, в методике E.P. Harvold отмечается как TM-PGN), Max-Mand - (межчелюстная разница); а также показателя, вошедшего в третью группу в зависимости от показателей первой и второй групп - Ap1uAp1I-DOP (угол Ap1uAp1I-DOP). У юношей построены все 3 возможные достоверные модели телерентгенографических показателей по методике E.P. Harvold, которые вошли во вторую группу в зависимости от показателей первой группы ( $R^{2}=$ от 0,616 до 0,940), а у девушек - только длина верхней и нижней челюстей $\left(R^{2}=0,857\right.$ и 0,792). Как у юношей, так и у девушек ко всем построенным моделям показателей второй группы, в зависимости от показателей первой группы, вошло расстояние Р-РТV. К двум моделям у юношей и в одной модели у девушек вошло расстояние Pt-N. Также к одной модели у юношей и девушек вошел угол краниального наклона (POr-NBa). Только у девушек к моделям входит передняя длина основания черепа (N-CC). Как у юношей, так и у девушек нами также построена возможная достоверная модель показателя третьей группы в зависимости от показателей первой и второй групп (угла Ap1uAp1I-DOP) (соответственно $R^{2}=0,626$ и $R^{2}=0,584$ ). И у юношей, и у девушек к построенным регрессионным уравнениям входит величина расстояния А-В. Кроме того, уюношей к регрессионному уравнению входит величина расстояния P-PTV; а у девушек - величина углов ANS-Xi-PM, MeGo-NPog и N-CF-A, а также межчелюстная разница Мах-Мапd. Ключевые слова: регрессионный анализ, цефралометрия, анализ Наrvold, юноши и девушки, ортогнатический прикус. 